\title{
A First Estimate for Canada of the Number of Birds Killed by Colliding with Building Windows
}

\section{Première estimation canadienne du nombre d'oiseaux morts par collision avec les fenêtres de bâtiments}

\author{
Craig S. Machtans ${ }^{1}$, Christopher H. R. Wedeles $^{2}$ and Erin M. Bayne $^{3}$
}

\begin{abstract}
Mortality from birds colliding with windows in buildings may be ecologically significant. Although data are sparse, we estimated the number of birds killed by this means in Canada. We made distinct models for three classes of buildings: houses, low-rise commercial and institutional buildings, and tall buildings. Estimates were developed using Monte Carlo-based simulations incorporating uncertainties and based on distributions that best fit available data or conceptual models. We estimate that about 25 million (range 16-42 M) birds are killed by colliding with windows in Canada annually. The assumptions used in our analyses are identified in detail so that subsequent efforts can address the uncertainties. Houses likely cause $90 \%$ of building-related mortalities, low-rise buildings slightly less than $10 \%$, and tall buildings approximately $1 \%$. The disproportionate contribution of mortality caused by houses is a function of their relative number compared to the two other classes of buildings. Our review found that warblers and sparrows were the most commonly killed birds at low-rise and tall buildings, and insufficient information exists on species deaths at houses to determine proportions. Targeted mitigation for certain tall buildings and a segment of the low-rise building types could significantly reduce the total mortality for both these building types. Mitigation strategies are now widely available, including architectural guidance produced by numerous cities in North America as well as specific products suitable for home use to reduce the number of birds colliding with windows.
\end{abstract}

RÉSUMÉ. La mortalité d'oiseaux par collision avec les fenêtres de bâtiments pourrait avoir une importance écologique. Malgré la rareté des données, nous avons estimé le nombre d'oiseaux morts de cette façon au Canada. Nous avons élaboré des modèles distincts pour trois classes de bâtiments : les maisons, les bâtiments commerciaux et institutionnels de faible hauteur, et les édifices. Nos estimations ont été faites à partir de simulations de Monte-Carlo tenant compte des incertitudes et fondées sur les distributions qui s'ajustaient le mieux aux données disponibles ou aux modèles conceptuels. Nous avons estimé qu'environ 25 millions (étendue : 16-42 millions) d'oiseaux sont morts à la suite de collisions avec les fenêtres chaque année au Canada. Les hypothèses émises dans notre analyse sont décrites en détail de façon à ce que les efforts subséquents puissent évaluer les incertitudes. Les maisons sont vraisemblablement responsables de $90 \%$ des mortalités relatives aux collisions, les bâtiments de faible hauteur d'un peu moins de $10 \%$ et les édifices d'environ $1 \%$. La contribution disproportionnée de la mortalité causée par les maisons est attribuable à leur nombre relatif comparativement aux deux autres classes de bâtiments. Selon notre revue de littérature, les parulines et les bruants sont les oiseaux qui se frappent le plus communément sur les bâtiments de faible hauteur et les édifices. Les données sont insuffisantes pour établir la proportion des espèces qui se frappent mortellement sur les fenêtres de maisons. Des mesures d'atténuation ciblées pour certains édifices et bâtiments de faible hauteur pourraient réduire significativement la mortalité totale sur ces structures. De nos jours, il existe des stratégies d'atténuation faciles d'accès, y compris des guides concernant l'architecture produits par de nombreuses villes en Amérique du Nord, de même que des produits spécifiques pour les maisons afin de réduire le nombre d'oiseaux se frappant mortellement dans les fenêtres.

Key Words: bird mortality; bird-window collisions; buildings; glass

${ }^{1}$ Environment Canada, ${ }^{2}$ ArborVitae Environmental Services, ${ }^{3}$ Integrated Landscape Management Group

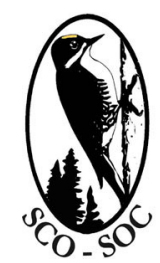

Sponsored by the Society of Canadian Ornithologists and Bird Studies Canada Parrainée par la Société des ornithologistes du Canada et Études d'oiseaux Canada

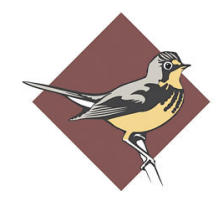

BIRD STUDIES CANADA
ÉTUDES D'OISEAUX CANANA 


\section{INTRODUCTION}

Unintentional anthropogenic mortality of birds has been the subject of considerable scientific and popular concern (e.g., Evans Ogden 1996, Partners in Flight 2005, City of Toronto 2007, Klem 2007). Various sources of mortality have been investigated, including cats (Blancher 2013), industrial activities (e.g., Nocera et al. 2005), and collisions with various structures (e.g., Longcore et al. 2012). Concern about mortality caused by windowed buildings has existed for decades (Townsend 1931, Ross 1946). High mortality caused by individual buildings or sites has been reported (O'Connell 2001, Gelb and Delacretaz 2006) and several studies have tried to correlate glass extent, reflectivity, and landscape features that lead to bird deaths (Klem et al. 2004, 2009, Hager et al. 2008, Gelb and Delacretaz 2009, Borden et al. 2010, Bayne et al. 2012, Hager et al. 2013). Very few attempts, however, have been made to quantify the number of birds killed at any sort of meaningful geographic scale. Klem's (1990) approximation of 97.6 - 975.6 million deaths annually in the United States, which the author himself noted as "speculative," stands out as an exception to this omission and is cited as a benchmark reference (Evans Ogden 1996, Gelb and Delacretaz 2006, New York Audubon Society 2007) despite its speculative nature (Best 2008). Not even a speculative estimate exists for Canada.

Bird mortality at buildings is almost always caused when birds collide with glass. During daytime there are two main mechanisms thought to cause collisions. First, birds may strike transparent panes when a breezeway or other narrow, glassedin feature is in their flight path, presuming they can fly right through it to reach habitat and/or sky on the other side (Ross 1946, Klem et al. 2009). Second, birds also strike reflective panes attempting to reach habitat or sky mirrored in the glass surface (Banks 1976, Klem 2006). Situational factors contribute to the propensity of buildings to cause mortality. Chief among these seems to be proximity to, and abundance of nearby vegetation, the location of bird attractants, i.e., feeders, and the glass surface area of the structure (Hager et al. 2008, Gelb and Delacretaz 2009, Klem et al. 2009, Borden et al. 2010, Hager et al. 2013). Greater vegetation abundance and its maturity, as well as the presence of bird feeders, are assumed to increase the potential number of birds that are available to collide with windows (Vale and Vale 1976, Edgar and Kershaw 1994, Chace and Walsh 2006). The visual link between vegetation and collisions likely means that most daytime collisions are associated with the lower levels of multistorey buildings (Gelb and Delacretaz 2006). At night, the amount of light emitted by a structure is thought to cause a 'beacon effect' attracting and confusing birds, leading to mortality as birds fly into the building's glass. This type of mortality is most pronounced during migration when birds are active at night (Drewitt and Langston 2008) and is exacerbated by low cloud cover when birds reduce the height at which they migrate (Newton 2008, Longcore et al. 2012).

The data upon which to base a national estimate of mortality is quite limited (Table 1) despite the perception that birdwindow collisions are a major source of avian mortality. Klem (1990) derived his estimates of mortality based on a study of two houses in rural and treed suburban settings and experiments of windows placed in a rural environment. Estimating an average per-building toll of 1 to 10 birds per year and multiplying by the number of buildings in the United States led to his oft-cited estimates. Banks's (1979) estimate of 3.5 million fatalities per year in the United States was based on the author's admittedly arbitrary estimate of 1 bird fatality per square mile. Dunn (1993) estimated that 0.65 - 7.7 birds are killed per home annually, but that estimate required a number of assumptions to extrapolate from a survey of window strikes in the winter at homes with an above-average number of feeders to a year-round rate for the general population. A number of studies of individual industrial-type, low-rise commercial and institutional buildings or groups of buildings have yielded per-building mortality rates considerably higher than those estimated by Klem (1990) and Dunn (1993), ranging from 8 to over 50 deaths/building/year (Table 1), and pointing out the need to consider them separately from houses. Most of those studies, however, were at buildings that the authors suspected had high mortality rates because of building architecture, e.g., reflective glass, or situational, e.g., horticultural, features, making them a biased representation of all buildings in general. Data on mortality at tall buildings in Toronto are collected by The Fatal Light Awareness Program (FLAP, www.flap.org), but the program was never designed to collect data for scientific purposes such as developing mortality estimates; data are highly biased to records from buildings known to kill birds. To our knowledge Hager et al. (2013) is the only bird-window mortality study that used a random sample of available buildings and adjusted totals for detectability to get unbiased estimates of mean mortality rates and variance.

Estimating the number of birds being killed from collisions with windows in Canada is the first step to understanding if regional or national population declines may be partially attributable to this type of mortality. Directing conservation efforts to include more than the traditional suite of mortality sources, i.e., intentional killing, habitat loss, specific industries, should be based on an understanding of the magnitude of the problem. No meta-analyses of buildingcaused bird mortality for Canada have been done, however, precluding the availability of objective results on which to base focused conservation action. Determining species susceptibilities is a critical next step; all studies we reviewed found that Passeriformes were the most prominent order 
Table 1. Rates of birds killed per building per year from studies of homes, low-rise, and tall buildings.

\begin{tabular}{|c|c|c|c|c|}
\hline $\begin{array}{l}\text { Building } \\
\text { Class }\end{array}$ & Birds/Bldg/Yr $\mathrm{r}^{\dagger}$ & Study & Location & Notes \\
\hline \multirow[t]{7}{*}{ Houses } & 33 (house 1) & Klem (1990) & Carbondale, IL & Study of two residences; both in bird rich \\
\hline & 26 (house 2) & & Westchester, NY & environments. \\
\hline & Mean $=1.5$ & Weiss and Horn (2009) & Illinois & Based on 242 responses to a homeowner survey. \\
\hline & $\begin{array}{l}\text { Mean }=1.7 \text { collisions } \\
0.7 \text { deaths }\end{array}$ & Bayne et al. (2012) & Edmonton, $\mathrm{AB}$ & $\begin{array}{l}\text { Based on } 1458 \text { responses to a homeowner survey } \\
\text { including rural:urban and feeder:not splits, partial } \\
\text { evidence of neighborhood age, and several other } \\
\text { covariates. It is unknown how many birds died away } \\
\text { from the homes (so not reported as a fatality) after } \\
\text { colliding. }\end{array}$ \\
\hline & range $0.65-7.70$ & Dunn (1993) & Continent-wide & $\begin{array}{l}\text { Based on } 1165 \text { responses to a survey on winter bird } \\
\text { mortality. }\end{array}$ \\
\hline & $\begin{array}{l}\text { range } 0.2-5.8 \\
\text { median }=1.7\end{array}$ & Hager et al. (2013) & $\begin{array}{l}\text { Rock Island and } \\
\text { Moline, IL }\end{array}$ & $\begin{array}{l}13 \text { of } 20 \text { buildings from a stratified random sample } \\
\text { of the area. Detectability adjusted estimate. }\end{array}$ \\
\hline & mean $=2.3$ & Bracey (2011) & Port Duluth, MN & $\begin{array}{l}\text { Survey of a sample of homes, extrapolated to a } \\
\text { broader community; corrected for searcher } \\
\text { detection. }\end{array}$ \\
\hline \multirow[t]{7}{*}{$\begin{array}{l}\text { Low-rise } \\
\text { buildings }\end{array}$} & mean $=28$ & Therres (1980) & Annapolis, MD & $\begin{array}{l}\text { Four four-storey office buildings joined by glassed- } \\
\text { in walkways; numerous woodlots in the immediate } \\
\text { area. }\end{array}$ \\
\hline & $\begin{array}{l}\text { range } 21-38 \\
\text { mean }=29\end{array}$ & O'Connell (2001) & Richmond, VA & $\begin{array}{l}\text { Four glass-surfaced office buildings in a corporate } \\
\text { office park with some mature second-growth forest. }\end{array}$ \\
\hline & $\begin{array}{l}\text { mean }=55(\text { campus } 1) \\
\text { mean }=24(\text { campus } 2)\end{array}$ & Hager et al (2008) & $\begin{array}{l}\text { Rock Island and } \\
\text { Elsah, IL }\end{array}$ & $\begin{array}{l}\text { Five buildings monitored on two horticulturally } \\
\text { enriched campuses. }\end{array}$ \\
\hline & range $8-11$ & Horn and Collins (2009) & Decatur, IL & $\begin{array}{l}\text { Variety of buildings; data corrected for searcher } \\
\text { efficiency. }\end{array}$ \\
\hline & $\begin{array}{l}\text { range } 3.2-52.1 \\
\text { median }=14.6\end{array}$ & Hager et al. (2013) & $\begin{array}{l}\text { Rock Island and } \\
\text { Moline, IL }\end{array}$ & $\begin{array}{l}7 \text { of } 20 \text { buildings from a stratified random sample of } \\
\text { the area. Detectability adjusted estimate. }\end{array}$ \\
\hline & mean $=28$ & Borden et al. (2010) & Cleveland, $\mathrm{OH}$ & $\begin{array}{l}\text { Average per structure of } 9 \text { buildings ( } 23 \text { façades) } \\
\text { and } 10 \text { connecting walkways. }\end{array}$ \\
\hline & $1.3 /$ ha or $1-10$ & Klem et al. (2009) & Manhattan, NY & Seventy-three building façades monitored. \\
\hline \multirow[t]{2}{*}{$\begin{array}{l}\text { Tall } \\
\text { buildings }\end{array}$} & $1-89$ & $\begin{array}{l}\text { Collister et al. (1996, 1997); Booth } \\
\text { and Collister (1998); B. Couronne, } \\
\text { personal communication }\end{array}$ & Calgary, $\mathrm{AB}$ & $\begin{array}{l}\text { Variable search effort between years and buildings, } \\
\text { no zero counts included. }\end{array}$ \\
\hline & $1-461^{\S}$ & $\begin{array}{l}\text { Fatal Light Awareness Program, M. } \\
\text { Mesure, personal communication }\end{array}$ & Toronto, ON & $\begin{array}{l}\text { Variable search effort between years and buildings, } \\
\text { no zero counts included. }\end{array}$ \\
\hline
\end{tabular}

Metrics not standardized because of original authors' presentation.

${ }^{*}$ Chicago and New York City data from collision programs were not available for analysis.

${ }^{\S}$ This is from the Top 23 data referenced in the Methods section, available at http://www.flap.org/pdfs/Top\%2020\%20Bird\%20Collision\%20Towers\% 20in\%20the\%20Greater\%20Toronto\%20Area.pdf. The exact value for the entire Fatal Light Awareness Program (FLAP) database depends on whether totals are taken from individual, formal street addresses or from single towers and link-ways within office complexes with the same street address. If the Toronto Dominion complex at 66 Wellington Street is considered one address, the upper limit becomes 851 .

represented in birds killed by windows but little work has been done comparing the relative vulnerabilities of families within that order.

Our main objective in this study was to provide the first estimate of avian mortality associated with bird-window collisions at buildings in Canada by synthesizing existing knowledge and incorporating sources of uncertainty in our estimates and therefore attempting to address the biases from using existing studies. Our secondary objectives were to summarize data on species' susceptibilities to collisions with buildings and to identify key data deficiencies that would enable better estimates that could be used in modeling so this form of mortality could be placed in a population context.

\section{METHODS}

Loss et al. (2012) describes best practices for using local and/ or biased data for mortality extrapolations. The details of our approach are outlined below but the overarching theme was to examine the nature of the biases in each data source, address these by weighting or excluding certain studies, using corrections and Monte-Carlo modeling of uncertainty, or selecting an analysis method to minimize biases.

Buildings were split into three categories for our estimates. In descending order of empirical evidence available to support our estimates, the three categories were: houses, low-rise commercial and institutional buildings, and high-rise buildings. We developed different models and calculated 
mortality independently for the three classes of buildings because we believe that different relationships exist between the characteristics of various types of buildings and their likelihood to cause avian mortality.

\section{Houses}

For this model 'houses' includes structures intended to shelter single families, specifically single detached houses, double/ row houses, duplexes, or mobile homes, consistent with the definitions provided by Natural Resources Canada (NRCAN; 2006). The number of houses in Canada and the number of birds each house kills form the basis for our estimate. We obtained data on the number of houses from NRCAN (2006) and updated them to 2010 based on Statistics Canada information on housing starts (Table 2). These two parameters can be further subdivided based on studies indicating that the number of birds in the vicinity of houses or killed at a single house depends whether that house is in an urban or rural setting, whether it has a bird feeder or not, and how old the house is (DeGraaf and Wentworth 1986, Mills et al. 1989, Dunn 1993, Bayne et al. 2012). Our rural:urban proportion was from the combination of NRCAN (2006) and Canada Post data on rural addresses. The proportion with feeders (20\%) is from Dunn (1993) and references therein but assumes $+/-5 \%$. The variance was applied because the cited surveys did not discriminate between feeding birds or other wildlife and the surveys are often based on number of adults who feed wildlife, rather than households. Also, other comparable surveys in the United States have found $~ 17 \%$ of that population "feed birds and other wildlife" (U.S. Department of the Interior et al. 2012).

Table 2. Number of houses in Canada by age class (their classes) from Natural Resources Canada (2006) and the 2006 Census (Statistics Canada 97-554-XCB2006022) with updates for recent housing starts from quarterly updates of the Canada Housing and Mortgage Corporation.

\begin{tabular}{cc}
\hline \hline Age-class (years) & No. Houses \\
\hline $0-9$ & $1,295,624$ \\
$0-9$ (updated starts to 2010) & 231,916 \\
$10-20$ & $1,295,953$ \\
$21-30$ & $1,574,686$ \\
$31-40$ & $1,829,506$ \\
$41-50$ & $1,324,623$ \\
$51-65$ & $1,369,469$ \\
$66-90$ & 619,116 \\
$>90$ & 586,242 \\
Total & $10,127,135$ \\
\hline
\end{tabular}

We assumed that house age is a surrogate for proximal vegetation maturity and abundance because the typical pattern of suburban development in Canadian cities is clearing/ building/[re]landscaping. The number of birds in urban areas is often tied to the amount and type of vegetation and increases as neighborhoods age (Chace and Walsh 2006 and references therein). We acknowledge that a robust model would estimate the vegetation cover and type in relation to houses throughout all of Canada, among other covariates such as location relative to species diversity and density gradients and other biotic resources. Unfortunately, such fine-scale parameterization of models is not possible at the national level. Bayne et al. (2012) found that survey participants who fed birds reported a higher incidence of bird-window collisions. Our assumption is that bird feeders attract birds to yards, thereby increasing local bird density and increasing the chance of collision, as has been demonstrated by Dunn (1993). The estimated number of birds killed at a single house, after accounting for the above factors, must further be adjusted by a correction for birds that died but were not found by homeowners or searchers.

We adjusted the number of kills in Bayne et al. (2012) to account for missed observations. The lower estimate of unaccounted mortalities was based on Zimmerling et al. (2013) who used 36 postconstruction monitoring studies of wind turbines to determine the combined effect of losses due to scavengers (62.4\% not scavenged) and searcher error (69.0\% found) on estimates of bird mortality. This resulted in $1 /(0.624 \times 0.69)=2.3$ missed birds for each one recorded . We considered this a lower bound because homeowners are not typically looking for dead birds, in contrast to paid observers in wind turbine studies. The upper estimate was taken from Dunn (1993) who speculated that up to five birds might die for every bird found in her study of window mortality associated with bird feeders. Longcore et al. (2012) also estimated post hoc that only $20 \%$ of dead birds are found in communication tower studies after accounting for scavenging, searcher efficiency, and incomplete sampling. This indicates that the 1:5 ratio may be conservative for (typically unsearched) areas around houses. We could not find support for any other upper bound. We used Bayne et al. (2012) as a primary source of information for the house model. The range of estimated mortality across studies from Table 1 is covered by the Bayne et al. (2012) data, when combined with the detectability correction above. Using their data also gave us the added benefit of being able to account for age effects in urban homes and the rural:urban split thereby improving our estimates. The exception to how Bayne et al. (2012) represents published ranges is the Klem (1990) data. That study seems unique in the frequency of searching (daily or nearly so) perhaps explaining why it is an outlier compared to the much larger sample sizes in the other studies.

A Monte-Carlo simulation was parameterized in Excel 2007 to provide a distribution of estimates from which we produced results. Table 3 summarizes our input parameters.

The simulation consisted of 10,000 iterations each with four components to simulate urban houses with/without feeders, and rural houses with/without feeders. For each iteration the simulation first randomly drew an age class, and then 
Table 3. Input parameters for Monte-Carlo simulation for calculating collision mortality from houses in Canada.

\begin{tabular}{lccc}
\hline \hline Parameter & Symbol & Range & Distribution Shape \\
\hline House Age & $\mathrm{A}$ & $1-120$ years & Uniform random within each age class \\
Number of Houses & $\mathrm{N}$ & See Table 2 & Uniform random \\
Kills at age per house & $\mathrm{K}(1-4)^{\dagger}$ & $0.1-3.1$ & From Bayne et al. (2012); see Fig. 1 \\
Percentage of Urban houses & $\mathrm{Pu}$ & $72-78 \%$ & Uniform random \\
Percentage of Houses with Feeders & $\mathrm{Pf}$ & $15-25 \%$ & Uniform random \\
Detectability Correction & $\mathrm{D}$ & $2.3-5.0$ & Uniform random \\
\hline \multirow{7}{*}{$\mathrm{K} 1$ is for urban houses without a feeder, K2 is for urban houses with a feeder, K3 is for rural houses without a feeder, and K4 is for rural houses with a } \\
feeder.
\end{tabular}

calculated a random age (A) within that class as well as assigning the number of houses $(\mathrm{N})$ to that estimate from the range specified in Table 2. Kills at age $\left(\mathrm{K}_{\mathrm{A}}\right)$ was then calculated from the custom distribution in Figure 1. The total number of houses in an age class was then adjusted to first correspond with the type of house (K1 to K4) and then to randomly vary that parameter within the range of both the rural:urban and feeder:no feeder proportions. For instance, the number of all urban houses with feeders could be as low as $10.8 \%$ of all houses (proportion of urban houses $=0.72 \times$ proportion of house with feeders $=0.15)$ or as high as $19.5 \%(0.78 \times 0.25)$. The correction factor for detectability (D) was randomly drawn from the range in Table 3. The final calculation for a single row in the simulation therefore was:

$$
\begin{aligned}
& \text { Estimate }_{\text {Urban without feeder }}=\mathrm{K} 1_{\mathrm{A}} \times \mathrm{N}(\mathrm{Pu} \times(1-\mathrm{Pf})) \times \mathrm{D} \\
& \text { Estimate }_{\text {Urban with feeder }}=\mathrm{K} 2_{\mathrm{A}} \times \mathrm{N}(\mathrm{Pu} \times \mathrm{Pf}) \times \mathrm{D} \\
& \text { Estimate }_{\text {Rural houses without feeder }}=\mathrm{K} 3_{\mathrm{A}} \times \mathrm{N}([1-\mathrm{Pu}] \times[1-\mathrm{Pf}]) \times \mathrm{D} \\
& \text { Estimate }_{\text {Rural houses with feeder }}=\mathrm{K} 4_{\mathrm{A}} \times \mathrm{N}([1-\mathrm{Pu}] \times \mathrm{Pf}) \times \mathrm{D}
\end{aligned}
$$

Each component in a simulation was therefore an estimate for the number of houses in one of the eight age classes in one of the four modeled circumstances, i.e., rural/urban and feeder/ not. The total estimated kills for each one of the four modeled circumstances was therefore the sum of the means for each of the eight age classes.

\section{Low-rise commercial and institutional buildings}

Buildings in this category are less than 12 storeys tall and include those used for all manner of services and businesses (Table 4). The majority of literature on bird deaths at low-rise commercial and institutional buildings we reviewed is biased toward sites with high mortality; typically at locations where there are many birds present because of lush landscaping and at buildings with a high amount of glass (authors explicitly either noted a priori evidence of collisions and/or vegetation conducive to attracting birds). Building types were allocated to one of three classes (Table 4) that correspond with the likely amount of local vegetation and window area. Virtually windowless warehouses in urban deserts are at one end of the scale, while buildings with multistorey façades with mirror-
Fig. 1. Relationships used to compute number of birds killed per house from Bayne et al. (2012). Age data were not available for rural dwellings, so static values were used.

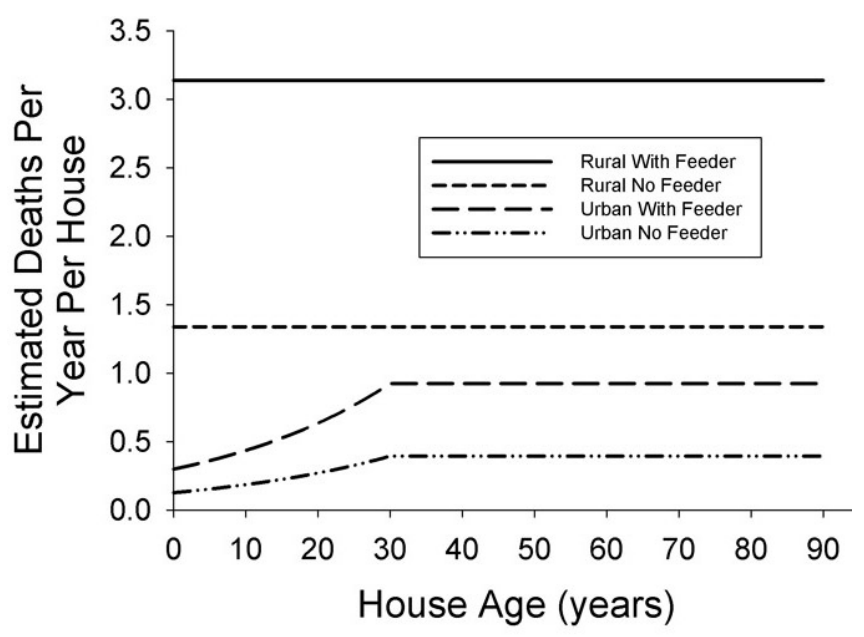

like glass on lushly vegetated grounds are the other extreme, notionally comparable to the statistical associations found by Hager et al. (2013). We knew our classification would contain errors and adjusted for that in our simulation by assuming the total number of buildings in each class had a variance of $+/-10 \%$ that could either be due to our misclassification of buildings in each category or from survey error in building counts. Based on the existing literature (Table 1), we used a modal estimate for all low-rise buildings of one death per year (Klem 1990). For buildings in the 'Least Likely to Cause Mortality" (Least Likely) class we assumed a Poisson distribution with values of $\lambda$ from 0.4 to 1.4 to represent the frequencies with which birds are killed by collisions at buildings. Those specific values were chosen to bracket the estimate of one per year above (mode value of $\lambda(1.4)=1$ ) with the possibility that windowless warehouses with little or no surrounding vegetation may have a mode value of $0(\lambda=$ $0.4)$. The resulting distributions are shown in Figure 2, covering a range where the most frequent mortality rate caused by buildings in the lowest simulation was zero, while the most 
Table 4. Number and description of buildings in each broad class used in our simulation. Data from Natural Resources Canada (NRCAN; 2007). Numbers are not exactly as in NRCAN (2007) because we reduced some sectors to account for buildings over 12 storeys tall included in the original data.

\begin{tabular}{lcc}
\hline \hline Sector & Number & Examples \\
\hline Least Likely to Cause Mortality & & \\
Wholesale and warehousing & 45,868 & \\
Retail & 97,265 & wholesale distributors for foods, dry good, house wares \\
Food Services & 37,932 & car dealers, furniture stores, supermarkets, department stores \\
rOTAL & 181,065 & \\
romestaurants, food service contractors, pubs \\
Accommodation Services & 5344 & hotels, motels, recreational vehicle facilities, bed and breakfast establishments \\
Religious Organizations & 24,451 & churches, diocese offices, rectories \\
Information and Cultural Services & 8429 & publishing, broadcasting, libraries, telecommunication services \\
Other & 64,658 & sports stadia, golf clubs, casinos, marinas, funeral homes \\
TOTAL & 102,680 & \\
Most Likely to Cause Mortality & & \\
Offices & 86,153 & brokerages, banks, professional services, government buildings \\
Education & 16,512 & elementary and secondary schools, colleges, universities \\
Health Care & 47,001 & offices with medical practionners, hospitals, nursing homes \\
TOTAL & 149,666 & \\
\hline
\end{tabular}

frequent mortality by buildings in the highest simulation was one bird per year.

Because we did not have a single distribution, we randomly generated 10,000 Poisson counts for each distribution and multiplied each row result by a single estimate of buildings in that category taken as random number of the NRCAN (2007) estimate for this type of building $(181,065+/-10 \%)$. We then took the average of the 11 estimates (one for each $\lambda$ value) in each row of the simulation, giving us 10,000 average estimates. No additional adjustment was made for detectability because the range of our distributions was already very liberal.

The same approach was used for buildings classified as 'Somewhat Likely to Cause Mortality' (herein 'Somewhat Likely'). We could not find literature sources to bound estimates for this class of buildings. We therefore considered this class to fill the range of likelihood between the 'Least Likely' class and values toward the lower end of the 'Most Likely' class. We modeled 12 distributions where $1.6 \leq \lambda \leq$ 3.8 and summarized them in the same way as the previous simulation.

We believe the least biased estimates for buildings in the category of "Most Likely to Cause Mortality" (herein 'Most Likely') were the Horn and Collins (2009) and Hager et al. (2013) estimates because both sampled buildings with varying amounts of glass and included adjustments for scavenging and searcher efficiency ( 8 - 11 birds/building/year and median of 14 birds/building/year for this building class, respectively). However, published accounts range as high as 50 - 55/ building/year (Hager et. al. 2008, 2013) so these higher values are also reflected in our estimate to include all reported estimates. We selected a negative binomial distribution that peaked at 8 - 12 deaths/building/year, but still retained a long enough tail to ensure that documented high kill rates were included in our simulation (parameters $\mathrm{N}=0.4$ and $\mathrm{p}=0.23$, Fig. 3). Another 10,000 values were estimated for this building category. Following advice in Loss et al. (2012), this resulted in weighting our simulations to what we considered least biased input data, i.e., the two detectability-corrected studies, but still allowing other study results to influence our simulations.

Fig. 2. Lower and upper endpoint Poisson distributions used in modeling mortality at low-rise buildings that were 'Least Likely' to cause collision mortalities.

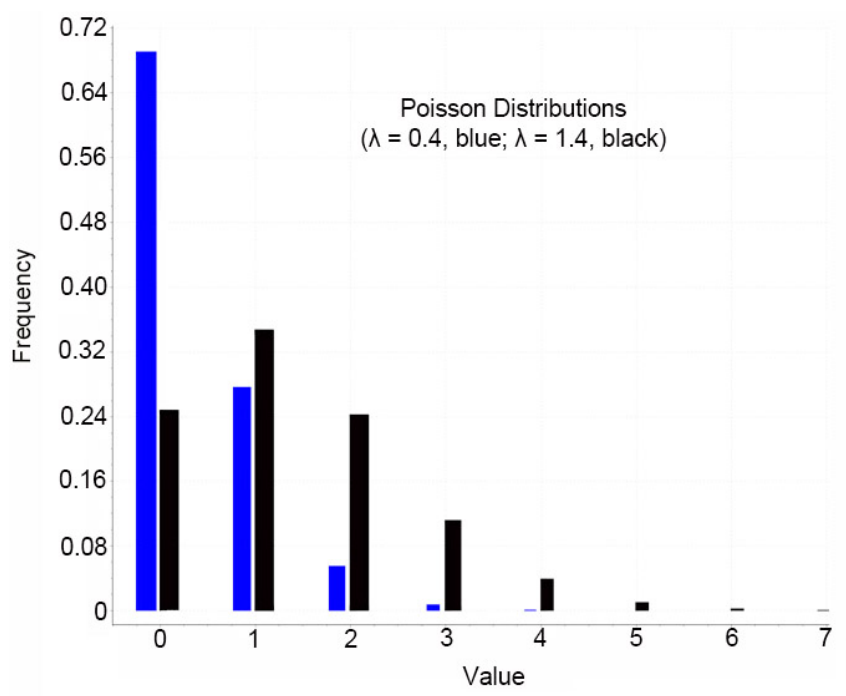


Fig. 3. The negative binomial distribution used to estimate kills per building per year in our Monte-Carlo analysis for low-rise commercial and institutional buildings that we categorized as 'Most Likely' to cause mortality in Canada.

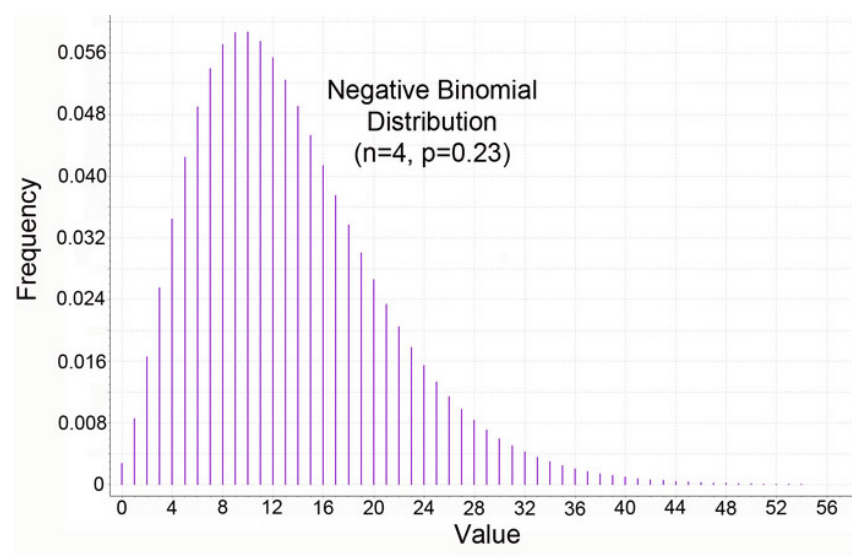

The final estimate of mortality for low-rise commercial and institutional buildings was produced by adding the rows from each of the three classes of buildings to produce 10,000 simulation results.

\section{Tall buildings}

The best available data on mortality associated with tall buildings comes from FLAP in Toronto; this was supplemented with data from the three years of work from a similar program in Calgary (Collister et al. 1996, 1997, Booth and Collister 1998). Neither of these programs was designed as a scientific survey to collect data for estimating bird deaths for nonsurveyed buildings. Chicago and New York data on tall building mortalities were not available for our analyses.

Data from FLAP were acquired through direct contact with the organization. An in-person visit (CHRW) to the Toronto city core was made to verify addresses and height of buildings to avoid totals that would have been included in our mid-rise building class. Additional detail or qualifications on the data for Calgary were obtained by contacting the original investigator (B. Couronne). Data on the number of tall buildings ( $>12$ storeys) for each city in Canada was available from http://skyscraperpage.com/cities/?s=0\&c=2\&p=3\&r=50\&10=1.

We estimated deaths from tall buildings using a ranked kill curve. FLAP data on the top killing buildings was used as the source (http://www.flap.org/pdfs/Top\%2020\%20Bird\%20Collision\% 20Towers\%20in\%20the\%20Greater\%20Toronto\%20Area.pdf ).

The number of deaths per year per building were plotted in descending rank order, creating an inverse exponential curve that was well defined by the data on the upper end of the curve $\left(\mathrm{R}^{2}=0.99\right)$. We reasoned that if most of the high-killing buildings are accounted for in the FLAP data, then the shape of a rank-order curve will be relatively well defined and allow a reasonable extrapolation to the low-kill buildings (not surveyed) that form the tail of said curve. The fitting function was $\mathrm{y}=\mathrm{y} 0+\mathrm{a} e^{-\mathrm{b} x}+\mathrm{c} e^{-\mathrm{d} x}$. The estimated number of annual deaths was calculated as the integral of the fitted function between 1 and 1921 (the number of tall buildings in Toronto). However, FLAP personnel state conclusively they are not surveying all high-kill buildings because of volunteer limitations (M. Mesure, personal communication). Given this, we also explored the sensitivity of the estimate to plausible additional mortality associated with buildings presently not surveyed by FLAP.

This curve fitting was repeated for the Calgary data with evaluation of the definite integral for the number of tall buildings $(1-303)$. We revised our detectability correction range from houses for tall buildings based on an average scavenging rates in Hager et al. (2012) and Ward et al. (2006 [sparrow data only]) for urban areas. We used the shortest search lag (one day) to compute $91.8 \%$ persistence from the former and used the stated value of $77 \%$ from the latter. Neither presented applicable searcher efficiency values. Averaging the two persistence rates, the lower end of the detectability correction became $1 /(0.844 \times 0.69)=1.72$. We used an upper end of 5.19 because our searcher efficiency term used for houses was likely very conservative given that two or more faces of tall buildings are not street-side and that many tall buildings have ledges and other architectural features above ground-level onto which dead birds may fall. Both situations prevent carcasses from being found, significantly lowering the searcher efficiency term of the detectability equation. This presented a case for a range of $0.25-0.5$ for this term, that when used with the $77 \%$ persistence from Ward et al. (2006), produces an upper limit of 5.19 birds missed for every bird found. Lower and upper estimates were derived from the proportion of all tall buildings in Canada represented by Calgary and Toronto, respectively:

Lower Bound $=($ Calgary estimate $\times 1.72 \mathrm{bird}$ killed $/ \mathrm{bird}$ found)/(\# Calgary buildings/\# Canada buildings).

Upper Bound $=($ Toronto estimate $\times 5.19$ birds killed/bird found)/(\# Toronto buildings/\# Canada buildings).

\section{RESULTS}

Table 5 provides a summary of the estimates of avian mortality. The sum of the mean mortalities from houses, lowrise buildings and tall buildings is 24.9 million. Houses contribute approximately $\sim 90 \%$ of building-related mortalities, low-rise buildings cause slightly less than $10 \%$ and tall buildings less than $1 \%$. 
Table 5. Summary of the estimates of bird mortality caused by bird-window collisions at different types of buildings in Canada.

\begin{tabular}{lcccc}
\hline \hline Building Class & $\begin{array}{c}\text { No. of Buildings in } \\
\text { Canada }\end{array}$ & $\begin{array}{c}\text { Mean estimated annual bird } \\
\text { deaths }\end{array}$ & SD & Min \\
& $10.1 \mathrm{M}$ & $22.4 \mathrm{M}$ & $2.4 \mathrm{M}$ & $15.8 \mathrm{M}$ \\
Houses & 441,000 & $2.4 \mathrm{M}$ & $30.5 \mathrm{M}$ \\
Low-mid Rise & 6200 & $64,000^{\dagger}$ & $1.1 \mathrm{M}$ & 300,000 \\
Tall Buildings & & $100,000^{\ddagger}$ & 43,000 & 13,000 \\
& $10.6 \mathrm{M}$ & $24.9 \mathrm{M}$ & 82,000 & 13,000 \\
Grand Total & & - & 149,000 \\
\hline
\end{tabular}

Based on existing Fatal Light Awareness Program (FLAP) data only.

Based on existing FLAP data supplemented to account for unsurveyed buildings (see text).

\section{Houses}

Collisions at individual houses in Canada were estimated to kill between 0.3 and 15.7 birds per year depending on whether houses were rural or urban and if the residents fed birds. The estimated average annual number of birds killed, after accounting for detectability error, was 22.4 million \pm 2.4 million (SD; Fig. 4A). Our simulations produced upper and lower bounds of 15.8 million and 30.5 million, respectively.

The largest proportion of houses in Canada are urban and do not have bird feeders, accounting for $37 \%$ of the individual total estimate deaths, in spite of having the lowest estimated per-house mortality rate (Fig. 4B). Urban houses with feeders typically contributed $22 \%$ of the total, while rural houses with and without feeders contributed $16 \%$ and $26 \%$, respectively. Homes in the 21 - 65 year age categories contributed most of the deaths because of the lower mortalities attributed to younger houses (Fig. 1) and the lower number of older homes in Canada (Table 2).

\section{Low-rise commercial and institutional buildings}

We modeled a range of 0.4 to 55 deaths/building/year for lowrise buildings in Canada. The combined average annual mortality estimate from all such buildings, i.e., those from the 'Least,' 'Somewhat,' and 'Most' classes, is 2.4 million \pm 1.1 million (SD; Fig. 5A). Our simulation produced lower and upper bounds of 300,000 to 11.4 million, though these extreme values rarely occurred.

Buildings categorized as being 'Most likely' to cause mortality were disproportionately responsible for the majority of the total estimated mortality (Fig. 5B). More than $80 \%$ of mortality is caused by $<40 \%$ of low-rise buildings in Canada.

\section{Tall buildings}

The mean annual estimated mortality caused by collisions with tall buildings in Canada is 64,000 birds (Table 5). This is the average from 70 different simulations where each differs by either Calgary/Toronto or correction factor applied as per the methods section. Not adjusting for detectability, the total estimates of annual mortality for Toronto and Calgary, as computed from the area under the rank-kill curves, were 8779
Fig. 4. Estimates of bird mortality in Canada caused by collisions with windows in houses. Panel A shows results as a frequency distribution from all iterations (see Methods). Estimates were rounded to the nearest 0.5 million for graphing. Panel B is a box and whisker plot showing percent of the total annual mortality contributed by urban and rural houses with and without bird feeders. The stars above or below each box correspond to the percentage of the total buildings represented by that class $(68 \%, 17 \%$, $12 \%$, and $3 \%$ ). Lines in the boxes are medians, the 25 th and 75th percentiles are the box boundaries, the 10th and 90th percentiles are the whiskers, and the solid dots are the upper and lower 5 th percentiles.

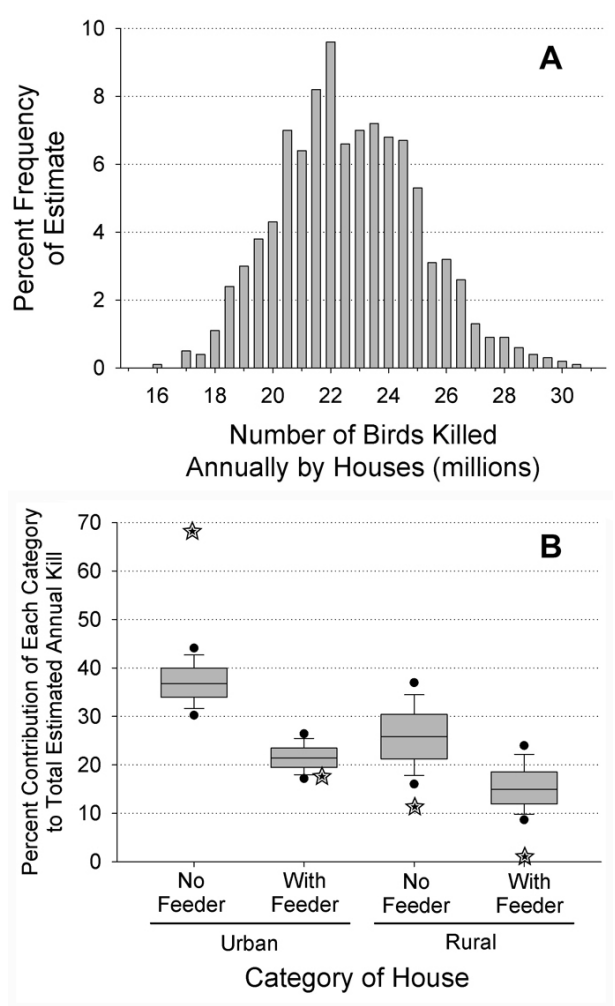


Fig. 5. Estimates of bird mortality in Canada caused by collisions with windows in low-rise commercial and institutional buildings. Panel A shows results as a frequency distribution from all iterations (see Methods). Estimates were rounded to the nearest 0.25 million for graphing and the graph was truncated at 8 million because higher estimates were not visible. Panel B is a box and whisker plot showing percent of the total annual mortality contributed by each of the three classes of buildings in the low-mid rise commercial building category. The stars above or below each box correspond to the percentage of the total buildings represented by that class $(42 \%, 24 \%, 35 \%$, respectively). See Fig. 4 for explanation of the box plots.
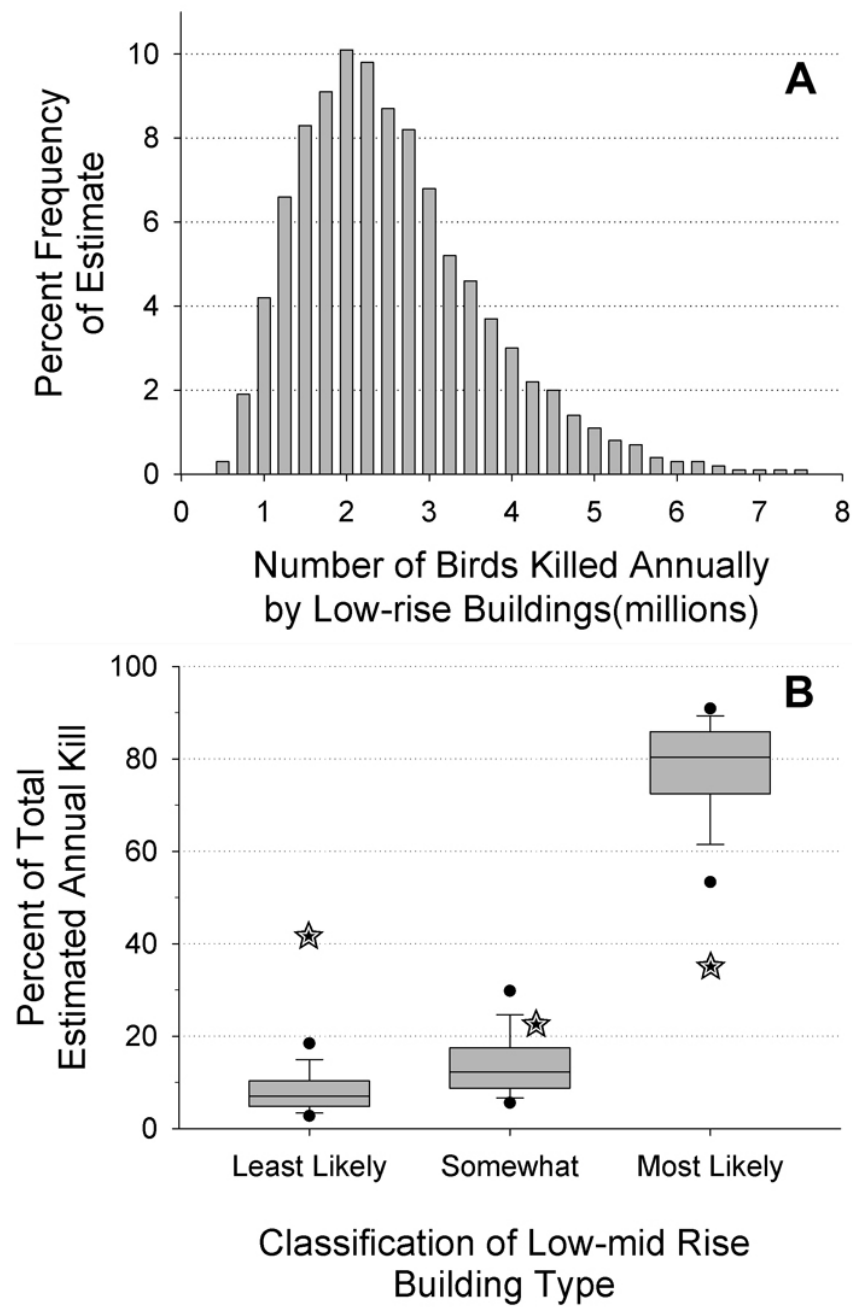

per year (for 1921 tall buildings) and 376 per year (for 303 tall buildings), respectively. The value of y0 in the Toronto function was 2.71 , and it was reached by the 115 th building in the extrapolated series, implying that all buildings between number 115 and 1921 would typically kill 2 - 3 birds per year. Applying the Toronto curve fit to the number of buildings in Calgary would yield an estimate of 4592 deaths per year for Calgary, more than order of magnitude greater than the observed data.

In exploring the implications of the strong assertion by FLAP staff that not all high-kill buildings are surveyed, we found that adding one more building for each five-building grouping in the rank order (adding the median of that grouping) increases the mean estimate for Canada by approximately $35 \%$ to 82,000 . Our final sensitivity check added buildings at the rate of one for the first five, two for the next five, three for the next five in a progression that assumed more buildings are missed at the lower end. This progression of as-yetunsurveyed buildings would yield a mean estimate for Canada of 100,000 deaths per year.

\section{Species susceptibilities}

Although the exact proportion of different species colliding with residential windows was not possible to determine from Bayne et al. (2012), and most studies on this building type had few species-specific data, passerines as a broad category dominated collisions. Participants in that study identified 48 species as dying at windows including various hawks, woodpeckers, waterfowl, and grouse.

We compared records of bird deaths from tall buildings from Toronto's FLAP program (2000-2007) and from the comparable program in Calgary (1995-1997; approx. 16,700 deaths) to published records from several studies of commercial and institutional buildings (Therres 1980, O'Connell 2001, Somerlot 2003, Hager 2008, Horn and Collins 2009 (approximately 800 deaths). For both types of larger buildings, Passeriformes were by far the most numerous (90.4\% tall buildings, $82.5 \%$ commercial and institutional buildings). Parulidae $(26.4 \%$ tall buildings, $21.2 \%$ commercial and institutional) and Emberizidae (23.5\%, $17.6 \%$ ) were the most commonly killed families by both types of buildings. Other families of species representing more than $3 \%$ total relative mortality from tall buildings were Turdidae (6.3\%), Certhiidae (3.4\%), and Paridae (3.3\%); for commercial and institutional buildings the families were Turdidae (14.8\%), Cardinalidae (6.3\%), and Fringillidae and Mimidae (both 4.0\%). Differences in the rates and ranks of relative mortality among families may be attributable to study locations, species ranges, and/or differential susceptibilities of species in combination with building characteristics.

\section{DISCUSSION}

Our analysis indicates that collisions at houses cause an order of magnitude more bird deaths than all other buildings combined. This result is driven by the numerical dominance of houses in the sample. Although the per-building mortality rate of houses is lower than that of the other buildings, $95 \%$ 
of the buildings included in this analysis were houses, and so the result is foreseeable with even very low average per-house mortality. Biased data was the primary hindrance for precision of our estimates, with most published studies targeting buildings that are known to kill birds. Finally, for both the mid-rise and tall building classes, a disproportionate amount of the mortality can be attributed to relatively few buildings, indicating that selective application of mitigation could substantially reduce total mortality, similar to that found for communication towers (Longcore et al. 2012).

\section{Uncertainties and bias}

The analyses presented here contained many assumptions that underscore the uncertainty associated with the calculated estimates. The lack of statistically valid surveys of buildings in all classes is the main problem with the data used for our extrapolations, a notable exception being Hager et al. (2013). In addition, the lack of detectability corrections for the majority of the studies also hinders the precision of extrapolations. The available literature on detectability for building studies, both scavenging rate and searcher efficiency, is slight (Ward et al. 2006, Hager et al. 2012, 2013). Surveys from other parts of Canada (preferably) or North America with different bird communities, greater rural representation, and varying neighborhood composition, i.e., vegetation communities, would greatly strengthen comparable analyses, but all results suggest that houses, particularly in rural areas, have considerable risk of killing birds.

Most published studies of low-rise commercial and institutional buildings self-admittedly focus on problem sites, thereby making them unrepresentative of all low-rise buildings. Our categorization of buildings into the three classes is simplistic and the building types we allocated to each class are based on crude categorizations of the data derived by Natural Resources Canada (2006). Nonetheless, we believe there is good rationale for broad categorizations based on patterns described in the literature that related mortality to the amount of glass and vegetation or inversely to level of development (e.g., Klem et al. 2009, Borden et al. 2010, Hager et al. 2013). There is also no published or anecdotal evidence that windowless warehouses in industrial parks kill as many birds as mirrored buildings surrounded by lush, bird-attracting vegetation. Only the 'Somewhat Likely' class of buildings lacked any direct published support for chosen distributions, but our choice became trivial given the strong dominance of the results by the 'Most Likely' class of buildings.

Our estimate for tall buildings was also based on a number of assumptions. The data provided by FLAP and the Calgary Bird Banding Society were excellent starting points for our analysis. However, because the data were not collected under an explicit sampling design, they are skewed toward buildings and sites believed to cause high levels of mortality rather than a random sample. The resulting lack of coverage of buildings that kill few or no birds per year means that the basic data were highly biased to an unknown degree, much like published estimates from other building types. It was because of this inherent bias that we used our rank-kill curve; this was the only approach that fairly accounted for at least some of the bias in the existing data. Finally, the death toll in Toronto is likely not representative of most other Canadian cities because of its location on the shore of Lake Ontario and that it contains $1 / 3$ of all tall buildings in Canada. The broad-front nature of passerine migrations means that overlapping a migration route is not a cause of high mortality per se in Toronto; it is likely the result of the dynamics of birds preparing or completing crossing the Great Lakes (Evans Ogden 1996). The significance of geography in making Toronto unlike most other Canadian cities is supported by other data and anecdotes. First, the difference is evident from the order of magnitude error produced by applying the curve from Toronto to Calgary. Second, one other effort to count birds killed under tall buildings in downtown Edmonton, Alberta found only a single dead bird after nine search days (all after cloudy nights), across 15 buildings during spring migration (S. Song, personal communication). Additionally, representatives from the two largest commercial real estate associations in Canada, Building Owners and Managers Association (BOMA) and Real Property Association of Canada (REALpac), indicate that the collision issue present in Toronto is apparently not as prominent in other Canadian cities where they manage or represent properties (C. Conway, R. Eickmeier, personal communication).

Toronto and Chicago produce relatively similar results from collision monitoring programs perhaps because of their similar geographic context and populations (city populations $\sim 2.7 \mathrm{M}$ ). The lead of Chicago's Bird Collision Monitors program indicates they collect about 3000 dead birds per year from the downtown core, and that proximity of the buildings to the lake and the nearby Chicago River seems to result in the most fatalities (A. Prince, personal communication). Given highly variable volunteer search effort within and among the programs, the Chicago average is not very different from Toronto's average of about 2100 per year. Clearly an expanded sample of cities in Canada would be necessary to determine the true range of inter-city variation and therefore improve the national estimate.

\section{Houses}

Rural vs. urban

Consistent with the model calibration shown in Figure 1, rural homes in general have a higher mortality rate than urban homes; they produced approximately $41 \%$ of the total estimated mortalities from only $23 \%$ of the houses. Nonetheless, because there are so many more urban homes, most bird mortality is estimated to occur in settlements. Rural homes are believed to cause disproportionate mortality 
because they often have more vegetation on their properties to attract a greater abundance and diversity of birds (Klem 1989, Dunn 1993, Drewit and Langston 2008). Because the categorization Bayne et al. (2012), and therefore our model, used to identify rural homes was based on postal code and therefore included villages and hamlets, the distinction between homes in the countryside and homes in population centers could not be explored.

With vs. without feeders

Approximately $39 \%$ of bird mortalities are estimated to occur at approximately $20 \%$ of homes because they have feeders. This is consistent with the assumptions used by Dunn (1993) in her estimate of mortalities at homes that feed birds, and of the notion of Klem $(1989,2006)$, who hypothesized that the best predictor of collision rate is the density of birds in the vicinity of glass. Feeders serve at attractants and so more birds are available at these locations to collide with glass. However, support for the density hypothesis is not universal (Hager et al. 2008, 2013) and behavior is believed to play a significant part in collision events.

\section{Home age}

Previous authors have noted a relationship between house/ neighborhood age and bird species abundance and/or diversity (Mills et al. 1989, Edgar and Kershaw 1994, FilippiCodaccionii et al. 2008). However, our results do not suggest a striking relationship between bird deaths and house age; approximately $70 \%$ of the urban deaths were predicted to be caused by the approximately $60 \%$ of houses in classes that cover the ages 21 - 65 years. The data upon which our model calibration was based (Bayne et al. 2012) did not include age information for rural houses and so we could not explore that dynamic for all the houses included in the simulation.

\section{Low-rise commercial and institutional buildings}

Low-rise buildings are estimated to cause slightly less than $10 \%$ of the total bird deaths caused by buildings. The vast majority ( $82 \%$ ) of mortality is attributed to the $1 / 3$ of all lowrise buildings that we classified as "Most Likely," while only $7 \%$ of the mortality is believed to be caused by the buildings in the "Least Likely" class (42\% of the total). As noted previously, buildings that cause high levels of mortality typically are in situations that attract birds and/or have glass features/characteristics that lead to bird strikes. The buildings studied by Therres (1980), O'Connell (2001), and Hager et al. (2008) that killed 24 - 55 birds/building/year were all in highly vegetated areas, e.g., woodlots, horticulturally enriched college campuses, and had a high amount of exterior glass.

\section{Tall buildings}

Perhaps the most surprising result from our analysis is the relatively small contribution of tall buildings to the total estimated mortality. Less than $1 \%$ of all mortalities are estimated to be caused by this class of buildings. This estimate may seem low given that bird mortality in urban centers is the focus of considerable popular attention. The heightened profile leads to a perception that this source of mortality is more significant than the estimates described here. An important situational factor not addressed in this analysis is the extent to which nighttime lighting is managed so as to control the beacon effect. For example, there was an $83 \%$ drop in mortality at McCormick Place in Chicago once lights were turned off at night (http://archive.fieldmuseum.org/ museum_info/press/press_birds.htm) and we did not account for any longitudinal effects in the data from the Lights Out program in Toronto. Although our analysis was based on some significant assumptions, even the most liberal inputs, assuming many more high-kill buildings or modeling results with different statistical approaches, resulted in a mean estimate of fewer than 500,000 deaths a year from tall buildings for all of Canada. However, the concern regarding mortality associated with tall buildings is usually couched within a broader context associated with mortalities occurring in urban areas, but it might be more appropriate to compare mortality at tall buildings with similar obstacles affecting birds primarily during migration, e.g., communication towers. Given our estimates of mortality associated with (predominantly urban) low-rise commercial buildings and the large portion of house-related mortality associated with urban homes, concerns regarding the impacts of all urban buildings on birds seem well founded.

\section{Species susceptibilities}

Our summaries of species vulnerable to collisions are similar to those of Arnold and Zink (2011), who in a much more detailed assessment of susceptibility noted species that migrate long distances or at night were more at risk of collisions than diurnal residents or nonmigratory species. We can only draw limited conclusions without detailed data on species susceptibility from houses, where the majority of kills occur. Recently, Hager et al. (2013) found that the majority of species present near buildings never died in a collision, including some of the most common species such as House Sparrow (Passer domesticus).

Species susceptibility, even at a gross level, apparently differs among obstacle type. Kills at tall buildings are dominated by passerines $(90 \%)$, but not so extremely as for communication towers (> 97\%; Longcore et al. 2013). Both rates are higher than the $\sim 80 \%$ reported for passerines at wind farms (Kuvlesky et al. 2007 and references therein). At the family level, sparrows are much more commonly killed at tall buildings than at communication towers (Longcore et al. 2013). Refer to Calvert et al. (2013) for a comparison of overall mortality estimates between all anthropogenic sources in Canada.

\section{Population relevance}

Approximately 5 billion birds breed in Canada, depending on calculation methodology and considering recent statistical 
advances (Blancher 2003, Matsuoka et al. 2012, P. Blancher, personal communication). This estimate roughly doubles for fall migration. The gross proportion of birds killed by buildings is therefore $<0.5 \%$ of all birds in Canada (see Calvert et al. 2013 for consideration of seasonal effects and conversion of our estimate to next year's adult bird equivalent). In spite of the apparently low gross rate of mortality, we believe it is premature to conclude that collision morality is not an important factor in decreasing population trends as was stated by Arnold and Zink (2011); more inclusive analyses and species-level population assessments are necessary (Schaub et al. 2011, Klem et al. 2012, Loss et al. 2012, Longcore et al. 2013). We strongly caution that until individual species susceptibilities and population estimates and dynamics are factored into cross-sector estimates of bird mortality (perhaps expanding on the analysis by Arnold and Zink (2011) when more data from Canada and the United States are available), the issue of relative importance of building-caused mortality cannot reasonably be addressed. This point was carefully articulated by Longcore et al. (2013). In addition, buildingcaused mortality is best considered as one of many sources of anthropogenic mortality in the context of cumulative impacts on birds. Losing even a few individuals of an at-risk species may be biologically significant. Although individual sources may not be significant when considered in isolation for some species, a broader perspective incorporating other sources of anthropogenic moralities is required to put both buildingcaused mortality and overall anthropogenic impacts in appropriate context (Loss et al. 2012, Calvert et al. 2013).

\section{Improving the estimates}

We suggest that the following are the most pressing needs for gathering data to calibrate future estimates:

1. Studies of the relative susceptibility of species to this source of mortality, especially at houses (e.g., Hager et al. 2013);

2. Modeling/quantitative assessments of the relative importance of this source of mortality on individual species (Loss et al. 2012);

3. Studies of collision rates at homes in other areas in Canada, sampling both rural and urban environments or other important gradients;

4. Studies to investigate detection error to facilitate extrapolation from surveys and sampling studies to corrected mortality estimates;

5. Sampling studies of mortality at low-rise buildings, including those with a variety of structural and situational characteristics;

6. Data collection/surveys to describe the characteristics of Canada's 'population' of low-rise buildings so that mortality estimates can be developed from sampling studies of mortality;
7. Sampling studies of mortality at tall buildings and in urban cores designed to include buildings with a variety of architectural features and buildings not thought to be predisposed to causing mortality, including standardizing search effort.

\section{Mitigation}

A recurrent theme in our estimates is the disproportionate mortality caused by some types of buildings. This finding has practical implications in terms of setting priorities or focusing mitigation activities. The highest gains (results per house) would come from focusing on homes that feed birds; following advice such as that from Klem et al. (2004) to place feeders within $1 \mathrm{~m}$ of windows can be implemented by homeowners at no cost and would greatly reduce bird mortality. Other options such as applying bird collision prevention film over windows (e.g., www.collidescape.org) or angling windows so that they reflect the ground instead of the surrounding habitat or sky (Klem 1990) may be appropriate at all classes of houses, but education and awareness efforts would be required to convince homeowners and builders of the benefits relative to cost.

For low-rise and tall buildings, recent bird-friendly building guidelines (e.g., City of Toronto 2007, Sheppard 2011) identify many techniques for managing the risk of bird collisions with glass, including the use of awnings and overhangs, patterned glass, opaque and translucent glass, window films, etc. Programs similar to Toronto's FLAP focusing on managing light pollution to reduce the beacon effect have been formed in $\sim 20$ U.S. cities (http://collisions. abcbirds.org/light.html). It would be a mistake to dismiss the absolute mortalities at tall buildings on the basis that they are proportionately lower than other building classes; on an individual basis, this class has the highest per-structure kill rates, the problem buildings are often known, and sound mitigation guidance noted above can reduce the mortality substantially.

The overall result that bird mortality at homes is much higher than at other types of buildings brings to the fore a significant mitigation challenge. To markedly reduce bird deaths, efforts need to focus on the millions of homes rather than merely thousands of tall buildings. However, because each house is, on average, not contributing a significant amount to the problem, novel and economically viable approaches will be needed to avoid an ecological tragedy of the commons (e.g., Vollan and Ostrom 2010).

\section{CONCLUSION}

We found that mortality from bird-window collisions was one of the largest causes of anthropogenic avian mortality in Canada (Calvert et al. 2013). Houses were by far the largest contributor to building-caused mortalities, causing an order of magnitude more mortality than low-rise buildings, which likely cause an order of magnitude more mortality than tall 
buildings. Because the majority of bird deaths appear to be caused by the millions of houses in Canada rather than the many fewer buildings in the other classes, considerable effort will be required to make headway in reducing total levels of avian mortality caused by buildings. We believe that the proportional relationship among the building types is solid in spite of the assumptions and uncertainties in our analyses that must be heeded when interpreting our results. Estimates could be improved by addressing the uncertainties above.

The population relevance of building-related mortality is not known given that impacts on individual species remain a significant uncertainty. We advocate that modeling and quantitative assessments supported by rigorous data collection be undertaken to estimate impacts. Although it will be very helpful to understand effects caused by buildings in general, it is important to place building-related mortality in a cumulative impacts context. Other sources of mortality, including cats, towers, breeding season vegetation clearing, automobiles, etc. need to be incorporated into conceptual and quantitative models to truly understand the impacts of anthropogenic mortality on birds and how that may be contributing to observed population declines. The imprecision in our estimates should also not be cause to focus solely on improvement of them; the number of birds being killed in Canada by colliding with buildings coupled with the proven mitigation already available means that reducing mortality is imminently achievable.

Responses to this article can be read online at: http://www.ace-eco.org/issues/responses.php/568

\section{Acknowledgments:}

We are grateful to M. Mesure and staff at FLAP for providing data and advice on collision-related mortality in Toronto, and to B. Couronne who kindly provided comparable data for Calgary. T. Longcore and two anonymous reviewers provided constructive comments on the draft. Funding was provided by Environment Canada.

\section{LITERATURE CITED}

Arnold, T. W., and R. M. Zink. 2011. Collision mortality has no discernible effect on population trends of North American Birds. PLoS ONE 6(9):e24708. http://dx.doi.org/10.1371/ journal.pone. 0024708

Banks, R. C. 1976. Reflective plate glass - a hazard to migrating birds. Bioscience 26:414.

Banks, R. C. 1979. Human related mortality of birds in the United States. Special Scientific Report, Wildlife No. 215. U. S. Fish and Wildlife Service. Washington, D.C.
Bayne, E. M., C. A. Scobie, and M. Rawson-Clark. 2012. Factors influencing the annual risk of bird-window collisions at residential structures in Alberta, Canada. Wildlife Research 39(7):583-592. [online] URL: http://www.publish.csiro.au/ paper/WR11179.htm

Best, J. 2008. Birds-dead and deadly: why numeracy needs to address social construction. Numeracy 1:1-14. http://dx.doi. org/10.5038/1936-4660.1.1.6

Blancher, P. 2003. Importance of Canada's boreal forest to landbirds. Canadian Boreal Initiative and the Boreal Songbird Initiative, Ottawa, Ontario, Canada. [online] URL: http:// www.bsc-eoc.org/download/borealbirdsreport.pdf

Blancher, P. 2013. Estimated number of birds killed by house cats (Felis catus) in Canada. Avian Conservation and Ecology 18(2): 3. http://dx.doi.org/10.5751/ACE-00557-080203

Booth, G., and D. Collister. 1998. Calgary Bird Banding Society 1997 Annual Technical Report. Calgary Bird Banding Society, Calgary, Alberta, Canada. [online] URL: http://www. calgarybirdbandingsociety.org/documents/ATR/CBBS\%20ATR\% 201997.pdf

Borden, W. C., O. M. Lockhart, A. W. Jones, and J. S. Lyons. 2010. Seasonal, taxonomic, and local habitat components of bird-window collisions on an urban university campus in Cleveland, OH. Ohio Journal of Science 110(3):44-52.

Bracey, A. M. 2011. Window related avian mortality at a migration corridor. Thesis, University of Minnesota, Duluth, Minnesota, USA.

Calvert, A. M., C. A. Bishop, R. D. Elliot, E. A. Krebs, T. M. Kydd, C. S. Machtans, and G. J. Robertson. 2013. A synthesis of human-related avian mortality in Canada. Avian Conservation and Ecology 18(2): 11. http://dx.doi. org/10.5751/ACE-00581-080211

Chace, J. F., and J. J. Walsh. 2006. Urban effects on native avifauna: a review. Landscape and Urban Planning 74:46-69. http://dx.doi.org/10.1016/j.landurbplan.2004.08.007

City of Toronto. 2007. Green development standard. Birdfriendly development guidelines. Fatal Light Awareness Program, City of Toronto, and Lights Out Toronto, Toronto, Ontario, Canada. [online] URL: http://www.toronto.ca/ lightsout/pdf/development guidelines.pdf

Collister, D. M., G. M. Booth, and B. Couronne. 1997. Calgary Bird Banding Society 1996 annual technical report. Calgary Bird Banding Society, Calgary, Alberta, Canada. [online] URL: http://www.calgarybirdbandingsociety.org/articles.php\#atr

Collister, D. M., G. Booth, G. Meyer, and B. Couronne. 1996. Calgary Bird Banding Society 1995 annual technical report. Calgary Bird Banding Society, Calgary, Alberta, Canada. [online] URL: http://www.calgarybirdbandingsociety.org/ documents/ATR/CBBS\%20ATR\%201995.pdf 
DeGraaf, R. M., and J. M. Wentworth. 1986. Avian guild structure and habitat associations in suburban bird communities. Urban Ecology 9:399-412. http://dx.doi. org/10.1016/0304-4009(86)90012-4

Drewitt, A. L., and R. H. W. Langston. 2008. Collision effects of wind-power generators and other obstacles on birds. Annals of the New York Academy of Sciences 1134:233-266. http:// dx.doi.org/10.1196/annals.1439.015

Dunn, E. H. 1993. Bird mortality from striking residential windows in winter. Journal of Field Ornithology 64:306-309.

Edgar, D., and G. P. Kershaw. 1994. The density and diversity of the bird populations in three residential communities in Edmonton, Alberta. Canadian Field-Naturalist 108:156-161.

Evans Ogden, L. J. 1996. Collision course: the hazards of lighted structures and windows to migrating birds. Special report prepared for World Wildlife Fund and the Fatal Light Awareness program. WWF, Toronto, Ontario, Canada. [online] URL: http://www.flap.org/pdfs/ccourse.pdf

Filippi-Codaccioni, O., V. Devictor, J. Clobert, and R. Julliard. 2008. Effects of age and intensity of urbanization on farmland bird communities. Biological Conservation 141:2698-2707. http://dx.doi.org/10.1016/j.biocon.2008.08.006

Gelb, Y., and N. Delacretaz. 2006. Avian window strike mortality at an urban office building. Kingbird 56:190-198.

Gelb, Y., and N. Delacretaz. 2009. Windows and vegetation: primary factors in Manhattan bird collisions. Northeastern Naturalist 16:455-470. http://dx.doi.org/10.1656/045.016. $\underline{\mathrm{n} 312}$

Hager, S. B., H. Trudell, K. J. McKay, S. M. Crandall, and L. Mayer. 2008. Bird density and mortality at windows. Wilson Journal of Ornithology 120:550-564. http://dx.doi. org/10.1676/07-075.1

Hager, S. B., B. J. Cosentino, and K. J. McKay. 2012. Scavenging affects persistence of avian carcasses resulting from window collisions in an urban landscape. Journal of Field Ornithology 83:203-211. http://dx.doi.org/10.1111/ j.1557-9263.2012.00370.x

Hager, S. B., B. J. Cosentino, K. J. McKay, C. Monson, W. Zuurdeeg, and B. Blevins. 2013. Window area and development drive spatial variation in bird-window collisions in an urban landscape. PLos ONE 8(1):e53371. http://dx.doi. org/10.1371/journal.pone.0053371

Horn, J. C., and K. A. Collins. 2009. Bird-window collisions and factors influencing their frequency at Millikin University in Decatur, Illinois. Transactions of the Illinois State Academy of Science 101(Supplement):50.

Klem, D. Jr. 1989. Bird-window collisions. Wilson Bulletin 101:606-620.
Klem, D. Jr. 1990. Collisions between birds and windows: mortality and prevention. Journal of Field Ornithology 61:120-128.

Klem, D. Jr. 2006. Glass: a deadly conservation issue for birds. Bird Observer 34:73-81.

Klem, D, Jr. 2007. Avian mortality at windows: the second largest human sources of bird mortality on earth. Pages 244-251 in T. D. Rich, C. Arizmendi, D. Demarest, and C. Thompson, editors. Tundra to tropics: connecting birds, habitats and people. Proceedings of the 4th International Partners in Flight Conference, 3-16 February 2008, McAllen, Texas. University of Texas-Pan American Press, Edinburg, Texas, USA.

Klem, D. Jr., K. L. De Groot, E. A. Krebs, K. T. Fort, S. B. Elbin, and A. Prince. 2012. A second critique of 'Collision mortality has no discernible effect on population trends of North American Birds.' Plos One 6:e24708, Comments. [online] URL: http://www.plosone.org/annotation/listThread. action?root $=49197$

Klem, D. Jr., C. J. Farmer, N. Delacretaz, Y. Gelb, and P. G. Saenger. 2009. Architectural and landscape risk factors associated with bird-glass collisions in an urban environment. Wilson Journal of Ornithology 121:126-134. http://dx.doi. org/10.1676/08-068.1

Klem, D. Jr., D. C. Keck, K. L. Marty, A. J. Miller Ball, E. E. Niciu, and C. T. Platt. 2004. Effects of window angling, feeder placement, and scavengers on avian mortality at plate glass. Wilson Bulletin 116:69-73. http://dx.doi.org/10.1676/0043-5643 (2004)116[0069:EOWAFP]2.0.CO;2

Kuvlesky, W. P. Jr., L. A. Brennan, M. L. Morrison, K. K. Boydston, B. M. Ballard, and F. C. Bryant. 2007. Wind energy development and wildlife conservation: challenges and opportunities. Journal of Wildlife Management 71:2487-2498. http://dx.doi.org/10.2193/2007-248

Longcore, T., C. Rich, P. Mineau, B. MacDonald, D. G. Bert, L. M. Sullivan, E. Mutrie, S. A. Gauthreaux Jr., M. L. Avery, R. L. Crawford, A. M. Manville II, E. R. Travis, and D. Drake. 2012. An estimate of avian mortality at communication towers in the United States and Canada. PLoS ONE 7(4):e34025. http://dx.doi.org/10.1371/journal.pone.0034025

Longcore, T., C. Rich, P. Mineau, B. MacDonald, D. G. Bert, L. M. Sullivan, E. Mutrie, S. A. Gauthreaux Jr., M. L. Avery, R. L. Crawford, A. M. Manville II, E. R. Travis, and D. Drake. 2013. Avian mortality at communication towers in the United States and Canada: which species, how many, and where? Biological Conservation 158:410-419. http://dx.doi.org/10.1016/ j.biocon.2012.09.019

Loss, S. R., T. Will, and P. P. Marra. 2012. Direct humancaused mortality of birds: improving quantification of 
magnitude and assessment of population impact. Frontiers in Ecology and the Environment 10:357-364. http://dx.doi. org/10.1890/110251

Matsuoka, S. M., E. M. Bayne, P. Sólymos, P. C. Fontaine, S. G. Cumming, F. K. A. Schmiegelow, and S. J. Song. 2012. Using binomial distance-sampling models to estimate the effective detection radius of point-count surveys across boreal Canada. Auk 129:268-282. http://dx.doi.org/10.1525/auk.2012.11190

Mills, G. S., J. B. Dunning Jr., and J. M. Bates. 1989. Effects of urbanization on breeding bird community structure in southwestern desert habitats. Condor 91:416-428. http://dx. doi.org/10.2307/1368320

Natural Resources Canada. 2006. 2003 Survey of household energy use. Detailed statistical report. Natural Resource Canada, Office of Energy Efficiency, Ottawa, Ontario, Canada.

Natural Resources Canada. 2007. Commercial and institutional consumption of energy survey. Summary report June 2007. Natural Resources Canada, Office of Energy Efficiency, Ottawa, Ontario, Canada.

Newton, I. 2008. The migration ecology of birds. Elsevier, London, UK.

New York Audubon Society. 2007. Bird-safe building guidelines. New York Audubon Society, Albany, New York, USA.

Nocera, J. J., G. J. Parsons, G. R. Milton, and A. H. Freeden. 2005. Compatibility of delayed cutting regime with breeding bird and hay nutritional quality. Agriculture, Ecosystems \& Environment 107:245-253. http://dx.doi.org/10.1016/j. agee.2004.11.001

O'Connell, T. J. 2001. Avian window strike mortality at a suburban office park. Raven 72:141-149.

Partners in Flight. 2005. Clear the way for birds! Partners in Flight, Laurel, Maryland, USA. [online] URL: http:// digitalmedia.fws.gov/cdm/ref/collection/document/id/1414

Ross, R. C. 1946. People in glass houses should draw their shades. Condor 48:142.

Schaub, M., M. Kéry, P. Korner, and F. Korner-Nievergelt. 2011. A critique of 'Collision mortality has no discernible effect on population trends of North American Birds.' Plos One 6:e24708, Comments. [online] URL: http://www. plosone.org/annotation/listThread.action?root $=9659$

Sheppard, C. 2011. Bird-friendly building design. American Bird Conservancy, The Plains, Virginia, USA. [online] URL: http://www.abcbirds.org/newsandreports/BirdFriendlyBuildingDesign. pdf
Somerlot, K. E. 2003. Survey of songbird mortality due to window collisions on the Murray State University Campus. Journal of Service Learning in Conservation Biology 1:1-9.

Therres, G. D. 1980. Avian mortality at an office building in Annapolis, Maryland. Maryland Birdlife 36:91-98.

Townsend, C. W. 1931. Tragedies among Yellow-billed Cuckoos. Auk 48:602. http://dx.doi.org/10.2307/4076287

U.S. Department of the Interior, U.S. Fish and Wildlife Service, U.S. Department of Commerce, and U.S. Census Bureau. 2012. 2011 National survey of fishing, hunting and wildlife-associated recreation. U.S. Department of the Interior, Washington, D.C., USA. [online] URL: http://www. census.gov/prod/2012pubs/fhw11-nat.pdf

Vale, T. R., and G. R. Vale. 1976. Suburban bird populations in west-central California. Journal of Biogeography 3:157-165. http://dx.doi.org/10.2307/3038144

Vollan, B., and E. Ostrom. 2010. Cooperation and the commons. Science 330:923-924. http://dx.doi.org/10.1126/ science. 1198349

Ward, M. R., D. E. Stallknecht, J. Willis, M. J. Conroy, and W. R. Davidson. 2006. Wild bird mortality and west nile virus surveillance: biases associated with detection, reporting, and carcass persistence. Journal of Wildlife Diseases 42:92-106.

Weiss, R. E., and D. J. Horn. 2009. Project Prevent Collision. A study of bird window collisions in residential neighborhoods in Illinois. Transactions of the Illinois State Academy of Science 101:50.

Zimmerling, J. R., A. C. Pomeroy, M. V. d'Entremont, and C. M. Francis. 2013. Canadian estimate of bird mortality due to collisions and direct habitat loss associated with wind turbine developments. Avian Conservation and Ecology 18(2): 10. http://dx.doi.org/10.5751/ACE-00609-080210 